\title{
Novel Corona Virus (COVID-19): Current Strategies and Future Aspects
}

\author{
Ashish Shah 1,*iD, Jatinkumar Panara ${ }^{2}$ (D), Vanessa James $3, *$ iD \\ Department of Pharmacy, Sumandeep Vidyapeeth, Vadodara, Gujarat, India, shah_ashishpharmacy@yahoo.co.in (A.S.); \\ Department of R\&D, Cadila Pharmaceuticals, Ahmedabad, Gujarat, India \\ Ph.D. Scholar, Pharmacy Branch, Gujarat Technological University, Ahmedabad, Gujarat, \\ Indiavanessajames807@yahoo.com (V.J.); \\ * Correspondence: shah_ashishpharmacy@yahoo.co.in (A.S.);
}

Scopus Author ID 57214919105

Received: 23.08.2021; Revised: 1.10.2021; Accepted: 4.10.2021; Published: 31.10.2021

\begin{abstract}
Novel coronavirus (COVID-19) recently emerged as a new pandemic disease that affects millions of people worldwide. This disease considers as a potential threat to human society. Researchers are continuously working to identify virus structure, the pathophysiology of the disease, and possible treatment of the disease. Currently, to fight against the coronavirus, two major strategies have been adopted throughout the world; one is to target virus-cell machinery, and the second is to improve patient immunity. In this review, we have described detailed information about the structure and life cycle of the novel coronavirus, current therapy, and future strategies to fight against this pandemic disease. Computational methods are useful for understanding virus structure, disease pathology, and discovering novel anti-COVID agents. These methods can provide fast and efficient solutions to fight against this disease. We also highlighted the potential role of robotic technology and its importance in various clinical aspects. These robotic technologies may also play an important role in fighting COVID-19.
\end{abstract}

Keywords: COVID-19; FDA-approved drugs; vaccines; antibodies; natural products; artificial intelligence.

(C) 2021 by the authors. This article is an open-access article distributed under the terms and conditions of the Creative Commons Attribution (CC BY) license (https://creativecommons.org/licenses/by/4.0/).

\section{Introduction}

Coronavirus (2019-nCoV) or the severe acute respiratory syndrome coronavirus 2 (Covid-19-2) is quickly transmitting, which commenced in Wuhan city of Hubei province of China later to several parts of the world[1]. Coronaviruses (Subfamily- Coronavirinae) are enveloped, single positive stranded RNA virus. There are six CoVs known to cause human diseases categorized into low pathogenic and highly pathogenic CoVs. Severe Acute Respiratory Syndrome (SARS) CoV is highly pathogenic which mainly infects lower airways causing fatal pneumonia[2]. Two events had occurred in the past due to beta coronavirus. In 2002- 2003, a coronavirus of bat origin with palm civet cats as intermediate hosts in China's Guangdong province affected 8422 persons and caused 916 deaths (mortality rate 11\%)[3]. In 2012, MERS-CoV of bat origin emerged in Saudi Arabia with dromedary camels as intermediate host affected 2494 persons and causing 858 deaths (fatality rate 34\%)[4]. In December 2019, adults in Wuhan were admitted to the hospital with an unknown cause considered as severe pneumonia [1]. Samples were tested positive, which were accumulated from the market, denoting the origin of the outbreak[5]. 
In initial cases, the epidemic initiated from the Hunan Seafood market, but the increase in the number of cases and the evidence of human-human transmission was confirmed when healthcare practitioners contacted an infected patient. On $7^{\text {th }}$ January 2020, the virus was identified and characterized with Real-time reverse transcription-polymerase chain reaction (RT-PCR) and next-generation sequencing as coronavirus having $>95 \%$ homology with bat coronavirus and $>70 \%$ similarity with the SARS-CoV[6]. SARS-CoV is Betacoronavirus likely occurring in Chrysanthemum bats with pangolins and snakes as intermediate hosts[7]. The virus is present in huge amounts in infected people with approx a billion RNA copies per $\mathrm{ml}$ of sputum and can stay on contaminated surfaces longer than a week [8]. The incubation period is 2-14 days [6]. Classes of all ages are at risk of the virus, especially children and elderly persons with co-morbidities are more prone to infection. In the incubation period, persons who are asymptomatic are the main sources of infection and serve an important role in epidemic prevention and control[9] - respiratory droplets transmitted through inhalation or contact are the major source of transmission. The initial symptoms involved are fever, cough, dyspnea, myalgia or fatigue, sputum production, headache, hemoptysis, and diarrhea. Some cases progressed to acute respiratory distress syndrome (ARDS), acute cardiac injury, acute kidney injury (AKI), and shock[6]. Diagnosis comprises of patients having moderate or severe symptoms featured low lymphocyte counts, systemic inflammation and bilateral infiltrates from Chest X-ray and chest computed tomography which is more specific shows ground glass infiltrates. On January 30, 2020, the World Health Organization (WHO) declared COVID-19 to be a Public Health Emergency of International Concern (PHEIC) and considered as pandemic disease[10].

\section{Corona Virus Structure and Life Cycle}

Coronavirus $(\mathrm{CoV})$ is a type of large enveloped RNA virus that belongs to the family of coronaviruses. As per the international committee for the taxonomy of viruses, $\mathrm{CoV}$ is divided into four categories: alpha, beta, gamma, and delta, based on the viral genome sequence. The shape of the Cov looks spherical or moderately pleomorphic under an electron microscope. The average number of genomes is about 26-30kilobase [11,12]. Two-thirds of CoV contains viral polymerase, RNA synthetic materials, and two nonstructural polyproteins. The other one-third of the genome portion is divided into different structural units like protein spike (S), envelope (E), membrane (M), Nucleocapsid, and other helping proteins [13,14] (Figure1).

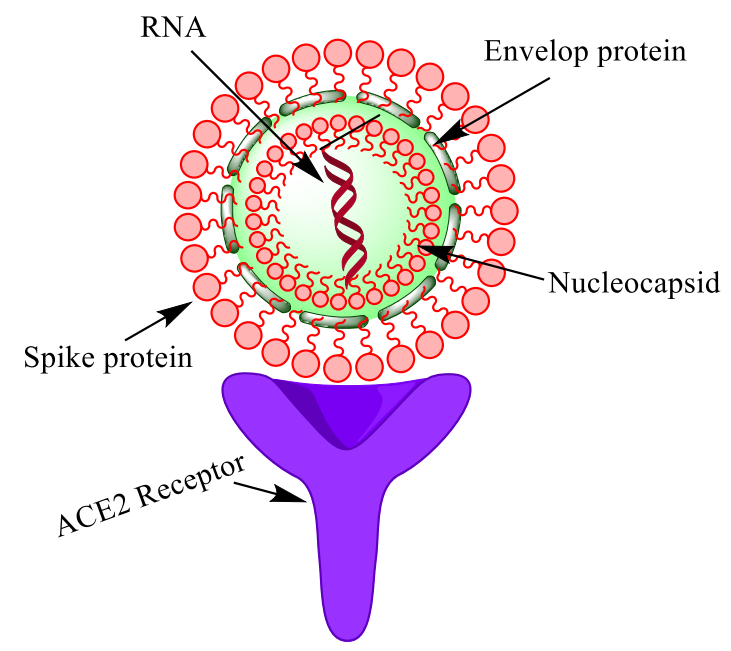

Figure 1. Structure of novel coronavirus. 
The viral life cycle stages of Cov are nearby similar to the normal viral cycle stages like attachment with the host cell, penetration, transcription, translation, assembly, and release. The life cycle of CoV starts with the attachment of the S1 domain of spike protein (S) with the host. This process makes a conformational change in the S2 subunit of $\mathrm{S}$ and ultimately promotes entry into the cell plasma membrane [15]. The virus utilized host cell receptors include different receptors like N-amino peptidase [16] angiotensin-converting enzyme-2 (ACE2) [17], Dipeptidase-4 (DPP4) [18], and 9-O-acetylated sialic acid [19]. Different types of CoVs utilize different sites. After entering the cytoplasm, viral RNA is transferred through ribosomal frameshifting and produces PP1a and PP1ab polyproteins. This protein will assemble and replicate the polymerase enzyme, which is involved in replicating the coronavirus. The next step is an assembly of viral products and release from the plasma membrane via exocytosis (Figure2).

It is believed that novel coronavirus is a type of beta coronavirus. This beta coronavirus contains spike protein (S) which plays an important role in binding. This protein binds with host cell surface membrane protein called angiotensin-converting enzyme-2 (ACE2) protein. This virus also contains several nonstructural proteins like RNA-dependent RNA polymerase (RdRp), coronavirus main protease (3CLpro), and papain-like protease (PLpro). The interaction between viral $\mathrm{S}$ protein and host cell surface protein ACE2 can be the major target Anti-CoVtherapy.It was reported in a cryo-EM structure that the binding affinity of SARSCoV-2 S protein is 10-20 times more than SARS-CoV [20].

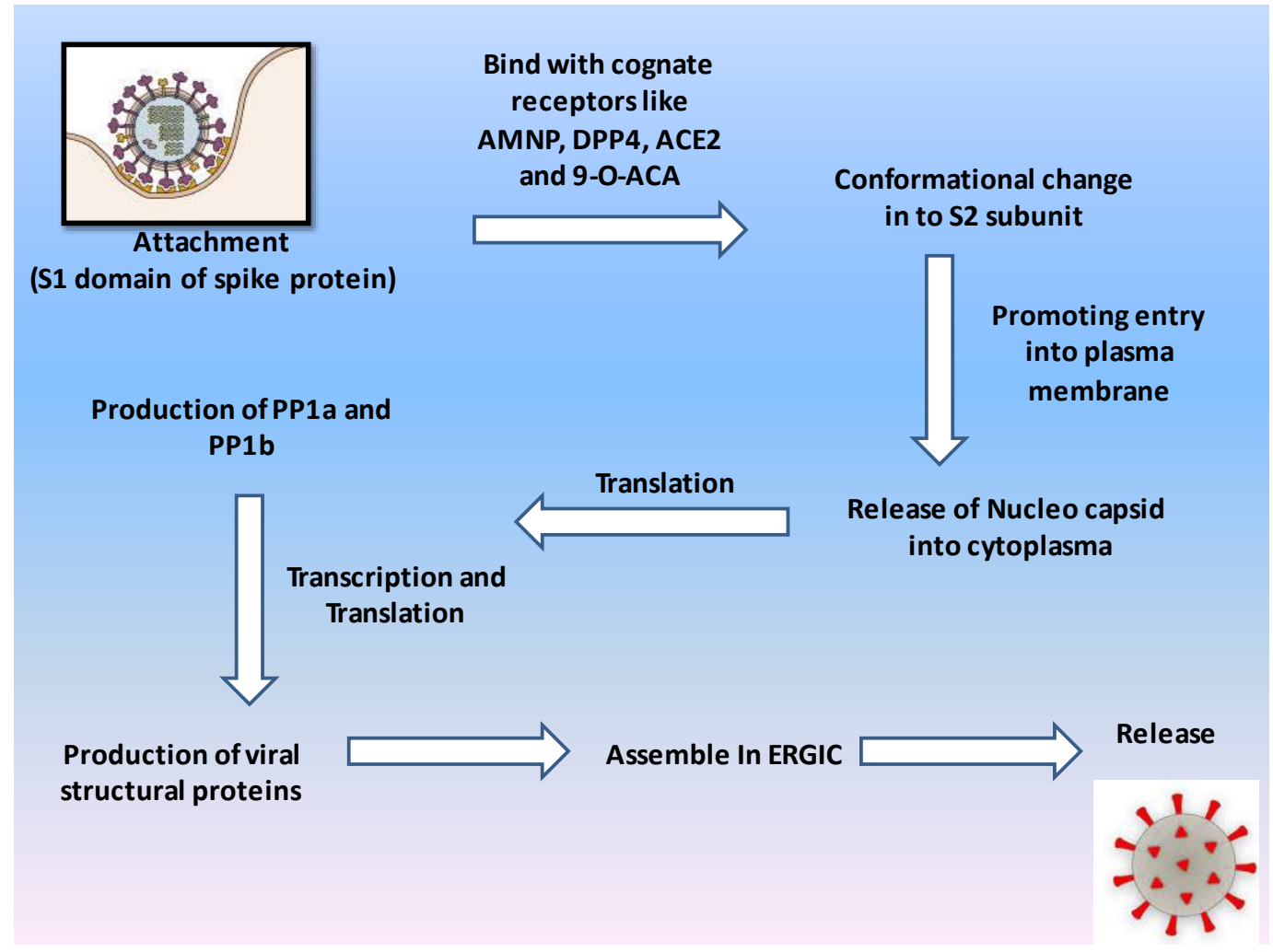

Figure 2. Life cycle of novel coronavirus.

\section{Current Strategies and future aspects to fight against COVID-19.}

\subsection{Use of existing drugs.}

Government authorities of the healthcare division are trying to identify the drugs which having target specificity towards Covid-19. In a virus, RNA synthesis occurs due to RNAdependent RNA polymerase (RdRp), several antiviral drugs that can block viral $R_{d} R_{p} R N A$ 
polymerase. The major target includes inhibition of spike protein(s), RNA-dependent RNA polymerase ( $\mathrm{RdRp}$ ), coronavirus main protease (3CLpro), and papain-like protease (PLpro) $[21,22]$. Current therapy against COVID-19 includes using existing drugs like remdesivir, chloroquine, hydroxychloroquine, arbidol, etc., and fixing dose of anti-HIV drugs in combinationlopanavir-ritonavir, which is currently in clinical trials[23].

The drug chloroquine and its derivative hydroxychloroquine might be effective against this disease due to its ability to block the replication of RNA synthesis [24,25]. The mechanism of chloroquine against COVID-19 is to boost basic $\mathrm{pH}$ in the virus compartment containing acidic $\mathrm{pH}$ through endosomes into the cell membrane and block the m-RNA replication. It can also inhibit nucleic acid replication, glycosylation of virus proteins, virus assembly, additional virus particle transport, virus release, and further processes from achieving its antiviral influence[26]. Another benefits of this drug are to inhibit COVID-19 origination at the site of receptor angiotensin-converting enzyme-2 or ACE-2 in the treatment of Covid-19[25].

Gilead Sciences, Inc. discovered Remdesivirto to treat Ebola virus infection, and presently it is in Phase-III of clinical trials for the treatment of COVID-19 [22]. Remdesivir is preferred in the prevention of COVID-19 infection due to the most promising and powerful antiviral activity. The drug remdesivir targets the receptor $R_{d} R_{p}$ and inhibits the RNAdependent RNA polymerase for replication of the viral genome. This drug is most significant than other antiviral drugs because of two advantages. The first one is the drug safety profile as it is already used in the treatment of Ebola infection, and the second is the number of clinical evidence which shows the potency of the drug.

The Australian researchers have found that Ivermectin is an inhibitor of Covid-19 causative virus (SARS-CoV-2) in vitro. Also added that a single treatment was able to affect an about 5000-fold reduction in COVID-19 virus at 2 days in cell culture. The latest advancement may lead to the improvement and trial of a novel clinical therapy for the pandemic. Combination therapy of drugs like sofosbuvir with ribavirin is useful for the Covid19 infection. This combination therapy can inhibit RNA synthesis as both drugs are closely bound to the receptor and block the RNA-dependent RNA polymerase [27].

Table 1. Repurposing of drugs to treat COVID-19.

\begin{tabular}{l|l|l|l} 
Sr. No. & Name of Drug & Category & Target candidate/Receptor \\
\hline 01 & $\begin{array}{l}\text { Chloroquine/ } \\
\text { Hydroxychloroquine [28] }\end{array}$ & Antimalarial & $\begin{array}{l}\text { ACE-2 (angiotensin-converting enzyme-2), } \\
\text { AT-2 (angiotensin-2) }\end{array}$ \\
\hline 02 & Azithromycin [2] & Macrolide Antibiotics & Ribosomal target \\
\hline 03 & Sofosbuvir [27] & Antiviral & $\begin{array}{l}\text { HCV-encoded proteins } \\
\text { NS5B polymerase }\end{array}$ \\
\hline 04 & Ribavirin[29] & Antiviral & RdRp(RNA-dependent RNA Polymerase) \\
\hline 05 & Penciclovir [30] & Antiviral & HSV DNA polymerase \\
\hline 06 & $\begin{array}{l}\text { Umifenovir } \\
\text { / Arbidol [5] }\end{array}$ & Antiviral & ACE-2 (angiotensin-converting enzyme-2) \\
\hline 07 & Favipiravir[31] & Antiviral & RdRp (RNA dependent RNA polymerase) \\
\hline 08 & Interferon Beta [7] & Interferon & $\begin{array}{l}\text { Interferes with viral replication by several } \\
\text { mechanisms }\end{array}$ \\
\hline 09 & Lopinavir [32] & Antiviral & $\begin{array}{l}\text { PLpro (papain-like protease), 3CLpro } \\
\text { (corona virus main protease) }\end{array}$ \\
\hline 10 & Ritonavir [32] & RpRd(RNA-dependent RNA Polymerase) \\
\hline 11 & Galidesivir [33] & Antiviral & RpRd(RNA-dependent RNA Polymerase) \\
\hline 12 & Triazavirin[34] & Antiviral & Nucleoside analogue, influenza virus \\
\hline 13 & Darunavir [35] & Antiviral & Type HIV-1 protease \\
\hline 14 & TMC-310911[35] & Antiviral & Protease inhibitor \\
\hline 15 & Remdesivir[36] & Antiviral & RdRp (RNA-dependent RNA Polymerase)
\end{tabular}

Currently, there are few drugs that are used, either single or with the combination of other drugs mentioned in Table 1. 


\subsection{Antibodies and vaccines.}

Polyclonal and monoclonal antibodies have specificity for different viral proteins like SARS-CoV-2 spike, envelope, and nucleo-capsidprotein. Researchers focus more on developing antibodies against the S-protein of novel coronavirus than other target proteins because of their ability to elicit an immune response. Various cytokines like chemokines, interferons, interleukins, lymphokines, etc., were produced and interfered with viral replication during the infection.[37]Cytokines storm has been reported to correlate with disease severity in SARS-CoV-2 infection due to its ability to act as a chemical signal in the immune system to pathogen invasion. ProSci Inc. has developed COVID-19 (SARS-CoV-2, 2019-nCoV) antibodies against the virus, and it is also effective on the virus receptor ACE-2 binding domain.[38]. To control, eradicate and prevent the occurrence, it is critical to develop safe and efficacious vaccines. As SARS and MERS viruses have nearby homology with SARS COV2, it helps design COVID-19 vaccines. Antiviral vaccines are of the following types: 1) Inactive or live attenuated viruses 2) Virus-like Particle (VLP) 3) Viral vectors 4) Protein-based 5) DNA based 6) mRNA based. There are 363 patents in CAS related to vaccine development which contains 175 patents for non-coronaviruses, and 188 patents of Anti-SARS and Anti-MERS, which shows immune response[37]. Till 8 April 2020, the worldwide COVID-19 vaccine R\&D scenario consists of 115 vaccine candidates. 78 - Confirmed active (73 projects are under exploratory or preclinical phase) and 37- not confirmed (status cannot be determined from information sources) (Figure 3) [39].

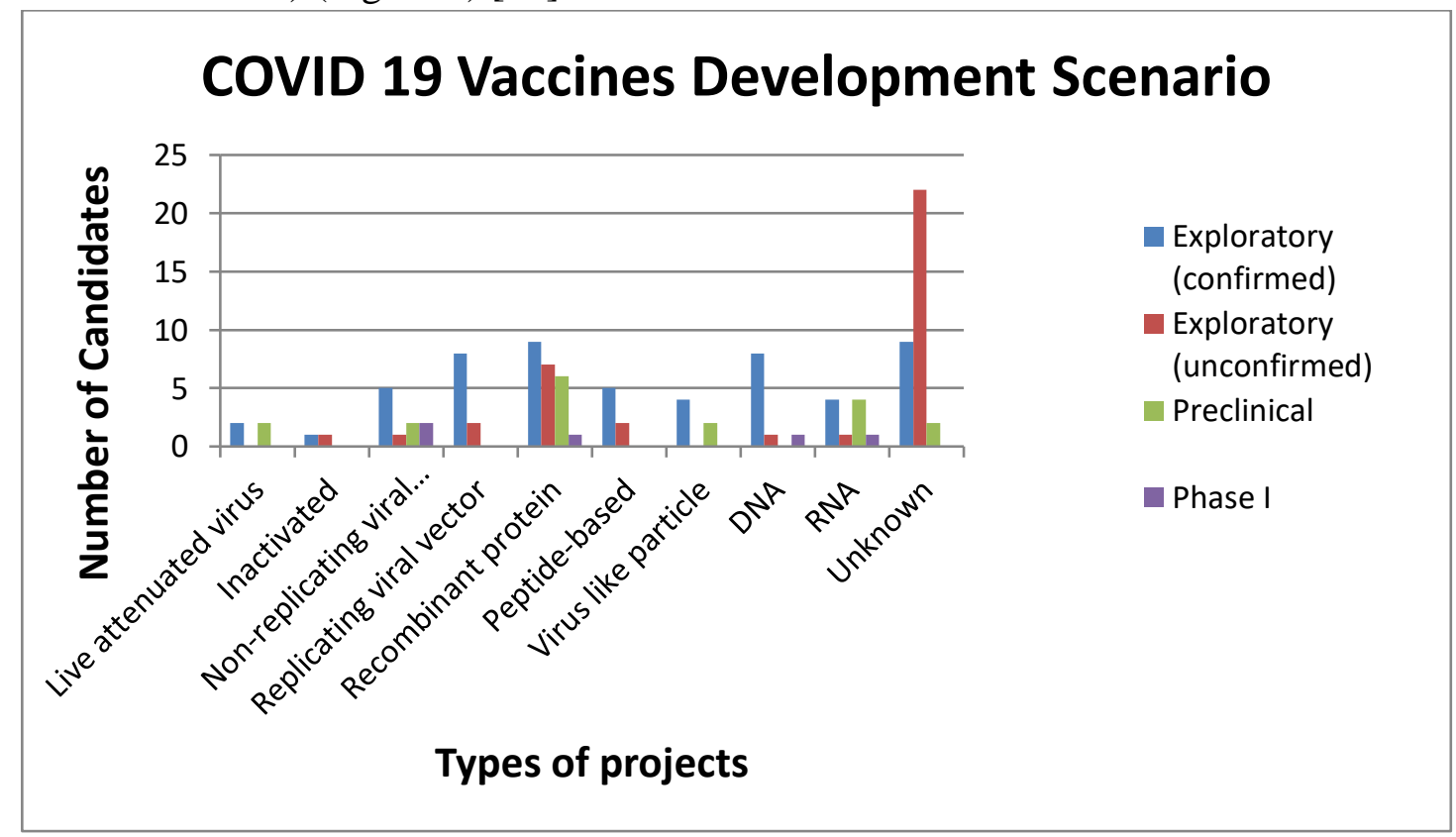

Figure 3. Different types of vaccines under development to fight against COVID-19.

\subsection{Natural Products Reported of Anti-SARS activity.}

Herbal medicines are a rich source of antiviral properties, and several mechanisms were identified to fight against the virus, which provides new wings for researchers to work on this area [40]. The natural products have the ability to interact with various stages of the viral life cycle, such as viral entry, replication, assembly, and release, to inhibit or reduce the activity of the virus [41]. They also have the capability for targeting virus-host-specific interactions against the receptors in the host cell. Several plant extracts were reported as anti-SARS activity 
in the past [42]. The active research on these plant extracts or phytoconstituents may provide an effective solution to fight against this pandemic disease (Table 2).

Table 2. Some examples of the plants reported for antiviral activity against the coronavirus.

\begin{tabular}{l|l|l|l|l|l}
$\begin{array}{l}\text { Sr } \\
\text { no }\end{array}$ & $\begin{array}{l}\text { Plant/ } \\
\text { Phytocnstituents }\end{array}$ & Family & Fraction used & Extract used & Mechanism/ Targeted part \\
\hline 01 & Lycoris radiata [40] & Amaryllis & Stem cortex & Ethanol & Unknown \\
\hline 02 & $\begin{array}{l}\text { Artemisia } \\
\text { annua[40] }\end{array}$ & Compositae & Full plant & Ethanol & Unknown \\
\hline 03 & Pyrossia lingua[40] & Polypodiaceae & Leaf of plant & Chloroform & Unknown \\
\hline 04 & $\begin{array}{l}\text { Lindera } \\
\text { aggregata[40] }\end{array}$ & Lauraceae & Root of plant & Ethanol & Unknown \\
\hline 05 & Isatisindigotica[43] & Brassicaceae & Phenolic compound & Methanol & $\begin{array}{l}\text { SARS-Cov 3CL protease } \\
\text { inhibitor }\end{array}$ \\
\hline 06 & Torreyanucifera[44] & Taxaceae & $\begin{array}{l}\text { Amentoflavone from } \\
\text { plant }\end{array}$ & Ethanol & $\begin{array}{l}\text { SARS-Cov 3CL protease } \\
\text { inhibitor }\end{array}$ \\
\hline 07 & $\begin{array}{l}\text { Myricetin and } \\
\text { scutellarein[45,46] }\end{array}$ & Resedaceae & $\begin{array}{l}\text { Polyphenolic } \\
\text { compound }\end{array}$ & $\begin{array}{l}\text { SARS-Cov helicase } \\
\text { inhibitor, nsP13, main } \\
\text { protease }\end{array}$ \\
\hline 08 & $\begin{array}{l}\text { Houttuynia cordata } \\
{[47]}\end{array}$ & Saururaceae & Leaf & $\begin{array}{l}\text { SARS-CoV 3CL protease } \\
\text { inhibitor; viral polymerase } \\
\text { inhibitor }\end{array}$ \\
\hline 09 & $\begin{array}{l}\text { Saikosaponins } \\
\text { (A,B, C,D) [48] }\end{array}$ & -- & Oleanane derivatives & -- & $\begin{array}{l}\text { Inhibits viral attachment and } \\
\text { penetration stages }\end{array}$
\end{tabular}

\subsection{Home remedies as an immunity booster.}

Common symptoms of Covid-19 are cold, fever, weakness, irritation in the neck, shortness in breathing, etc. This may occur due to the lower immunity level of the patient. As a part of precaution in COVID-19, some natural products are useful for improving immunity level and health [49]. Immunity is a major factor here we can have considered as per signs/symptoms of COVID-19. There are a few natural products; suggested to use as home remedies to improve immunity level $[50,51]$ listed in Table 3.

Table 3. Natural home remedies to boost immunity level.

1. Giloy

\begin{tabular}{l|l} 
Its ability to reduce the symptoms of common flu and is effective against chronic fever. It is an \\
expert as an immunity booster as compared with other home remedies also effective in digestion \\
and diabetes [52]. It can be used as by made juice of Giloy stem with a combination of clove \& \\
ginger for same.
\end{tabular}

\section{Elderberry}

\begin{tabular}{l|l}
\hline Elderberry extracts have several properties like antiviral, anticancer, anti-inflammatory. It is very \\
much useful for the covid-19 as a part of improvements in the immune system. It contains a major \\
section of flavonoids that are responsible for biological activity. Thus can be useful as the best home \\
remedy in any viral and bacterial infection disease [53].
\end{tabular}

3. Neem

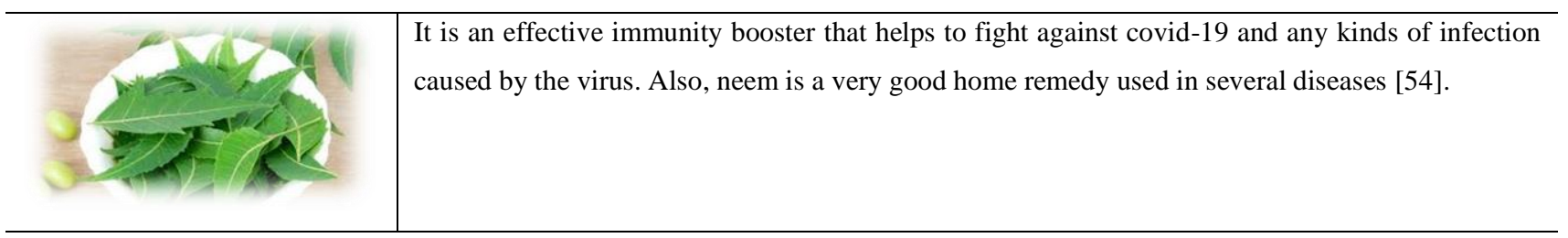

4. Amla 


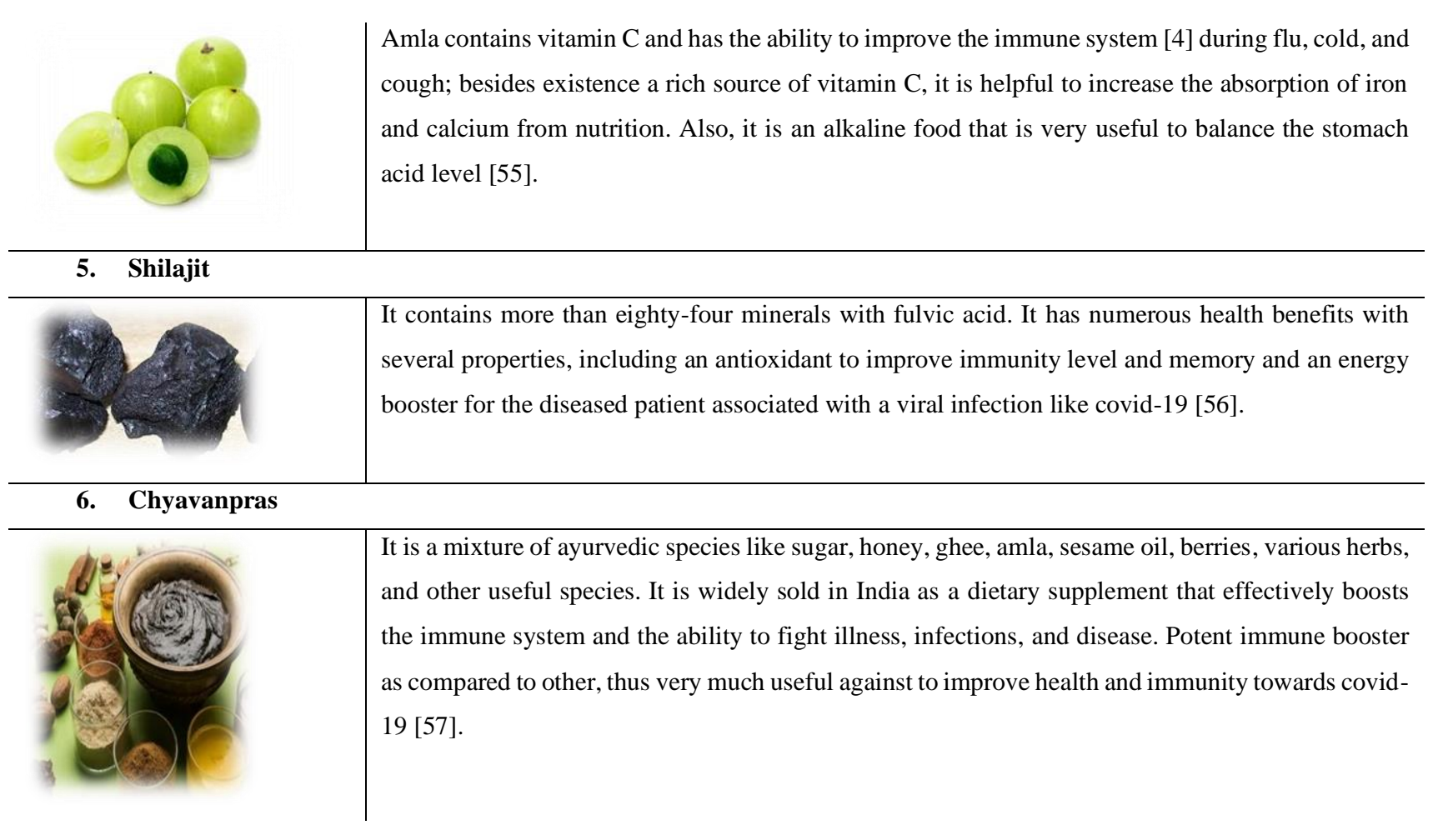

\subsection{Importance of artificial intelligence in CoVID-19 research.}

Artificial intelligence is the simulation of human intelligence by computers. It contains a subfield which is known as machine learning methods. Various computational tools can be useful for discovering new drugs and may provide important clues to researchers[58]. The technique called computer-aided drug design can be very useful for the discovery of new molecules against this disease. CADD is divided mainly into structure-based drug design (SBDD) and Ligand-based drug design (LBDD). SBDD uses the information of the 3D structure of disease protein, while LBDD applies when $3 \mathrm{~d}$ structure of disease protein is not available. It uses knowledge of existing molecules to design a new molecule, believing that new molecules may have higher potency and fewer side effects than previous ones. The SBDD can be performed using Docking and De-novo drug design methods. LBDD can be performed using QSAR, virtual screening using pharmacophore[59]. These computational techniques provide a fast and efficient way for the discovery of new Anti-COVID therapy. Using Bioinformatics tools, scientists are evaluating the biological structure of COVID-19, and already they succeeded. The structure of the spike protein and its binding mechanism with host identified. Another target called coronavirus main protease (3CLpro) was also identified. These targets have already been proved as potential Anti- COVID therapy. Apart from this, several nonstructural proteins were also identified. Researchers are discovering new potential agents using these targets by applying structure-based drug design methods. Day by day, research papers are increasing about establishing targets and finding novel agents using different computational methods[37,60].

\subsection{The role of robotics to combat CoVID-19.}

There is a number of examples reported especially in the case of infectious disease were medical, paramedical, or cleaning staff gets infected as they are directly or indirectly involved with patients. After the outbreak of Ebola 2015, it was discussed in the workshop organized by the White House Office of Science and Technology Policy and the National Science 
Foundation that there are three major areas where robotics technology can provide efficient solutions in pandemic disease, including clinical care logistics and quarantines. The development of robotic technology in the above area may provide benefits in the current situation of CoVID-19. To control disease, disinfection of non-contact ultraviolet surfaces by robotic technology [61] can be very useful because COVID-19 spreads from person to person via close contact or respiratory droplets and via contaminated surfaces. The contaminated surface includes metals, glass, or plastic, where this pathogen can survive up to some days. New robotic technology can be useful for identifying high-risk areas and sterilizing surfaces where contamination may occur. For the diagnosis purpose like temperature measurement in public areas, in-out hospital patient development of the thermal robotic system can be useful[62]. For the diagnosis of COVID-19, sample collection is done by nasopharyngeal and oropharyngeal swabs. This test requires skilled staff for the collection of samples, handling, and testing. In this whole procedure, robotic technology may speed up the process and reduce the risk of infection. Some people don't have symptoms, but they are vectors to spread this infection. In this case, the blood test is important to identify infection. Automated blood collection and testing can reduce the risk of infection. In a nutshell, COVID-19 disease can be the catalyst for the development of robotic technology. However, this task is challenging as robotic system development requires the social gathering of experts to develop such complex models[63].

\subsection{Convalescent plasma as a potential therapy for COVID-19.}

Convalescent plasma (CP) therapy can be useful tachnique for the prevention and treatment of various infectious diseases. This therapy was used successfully in the treatment 2009 H1N1 pandemic, SARS, and MERS infection. This therapy gave satisfactory results in terms of safety and efficacy [64-66]. In 2014, it was recommended by World Health Organization (WHO) to use convalescent plasma of patients who had recovered from Ebola virus disease. However, this therapy is unable to improve the survival rate because of o the absence of data of neutralizing antibody titration for stratified analysis[64,66]. The novel coronavirus has structural similarities with SARS and MERS, and clinical symptoms are also similar. Due to this, CP therapy might be a promising treatment option for COVID-19 treatment. Patients who are recovered from this disease may be valuable donor sources for CP therapy. The antibodies obtained from the recovered patient may have the ability to suppress viral growth. Therefore, it is advisable to test the safety and efficacy of convalescent plasma transfusion in SARS-CoV-2-infected patients.

\section{Conclusion}

Currently, almost all countries are fighting against this deadly disease. Researchers from all around the world are engaged to find specific therapy against novel coronavirus. To date, there is no specific drug/vaccine/antibodies that are clinically approved to treat this disease. To fight against novel coronavirus, approaches are adopted; one is to target the virus, and the second is to improve immunity. Currently, various FDA-approved drugs are used to treat patients. In addition, various vaccines and antibodies are under clinical trial. In this scenario use of artificial intelligence, techniques may provide a fast and innovative solution. Scientists are already using this kind of machine learning method to boost the research process. Applications of robotics technology are also useful to support the health care system. Finally, 
we want to add that in the absence of specific therapies, social distancing, immunity maintenance, primary precautions (like sanitization, wearing a mask, etc.) are helpful to break the chain of infection.

\section{Funding}

Non-funded.

\section{Acknowledgments}

Not applicable.

\section{Conflicts of Interest}

\section{There is no conflict of interest.}

\section{References}

1. Wang, C.; Horby, P.W.; Hayden, F.G.; Gao, G.F. A novel coronavirus outbreak of global health concern. Lancet 2020, 395, 470-473, https://doi.org/10.1016/S0140-6736(20)30185-9.

2. Gautret, P.; Lagier, J.C.; Parola, P.; Hoang, V.T.; Meddeb, L.; Mailhe, M.; Doudier, B.; Courjon, J.; Giordanengo, V.; Vieira, V.E.; et al. Hydroxychloroquine and azithromycin as a treatment of COVID-19: results of an open-label non-randomized clinical trial. Int J Antimicrob Agents 2020, 56, 105949, https://doi.org/10.1016/j.ijantimicag.2020.105949.

3. Chan-Yeung, M.; Xu, R.H. SARS: epidemiology. Respirology (Carlton, Vic.) 2003, 8 Suppl, S9-14, https://doi.org/10.1046/j.1440-1843.2003.00518.x.

4. Memish, Z.A.; Perlman, S.; Van Kerkhove, M.D.; Zumla, A. Middle East respiratory syndrome. Lancet 2020, 395, 1063-1077, https://doi.org/10.1016/S0140-6736(19)33221-0.

5. Lian, N.; Xie, H.; Lin, S.; Huang, J.; Zhao, J.; Lin, Q. Umifenovir treatment is not associated with improved outcomes in patients with coronavirus disease 2019: a retrospective study. Clinical microbiology and infection: the official publication of the European Society of Clinical Microbiology and Infectious Diseases 2020, 26, 917-921, https://doi.org/10.1016/j.cmi.2020.04.026.

6. Singhal, T. A Review of Coronavirus Disease-2019 (COVID-19). Indian J Pediatr 2020, 87, 281-286, https://doi.org/10.1007/s12098-020-03263-6.

7. Hung, I.F.; Lung, K.C.; Tso, E.Y.; Liu, R.; Chung, T.W.; Chu, M.Y.; Ng, Y.Y.; Lo, J.; Chan, J.; Tam, A.R.; et al. Triple combination of interferon beta-1b, lopinavir-ritonavir, and ribavirin in the treatment of patients admitted to hospital with COVID-19: an open-label, randomised, phase 2 trial. Lancet 2020, 395, 1695-1704, https://doi.org/10.1016/s0140-6736(20)31042-4.

8. Ong, S.W.X.; Tan, Y.K.; Chia, P.Y.; Lee, T.H.; Ng, O.T.; Wong, M.S.Y.; Marimuthu, K. Air, Surface Environmental, and Personal Protective Equipment Contamination by Severe Acute Respiratory Syndrome Coronavirus 2 (SARS-CoV-2) From a Symptomatic Patient. JAMA 2020, 323, 1610-1612, https://doi.org/10.1001/jama.2020.3227.

9. Jin, Y.H.; Cai, L.; Cheng, Z.S.; Cheng, H.; Deng, T.; Fan, Y.P.; Fang, C.; Huang, D.; Huang, L.Q.; Huang, Q.; et al. A rapid advice guideline for the diagnosis and treatment of 2019 novel coronavirus (2019-nCoV) infected pneumonia (standard version). Mil Med Res 2020, 7, 4, https://doi.org/10.1186/s40779-020-0233-6.

10. Jiang, F.; Deng, L.; Zhang, L.; Cai, Y.; Cheung, C.W.; Xia, Z. Review of the Clinical Characteristics of Coronavirus Disease 2019 (COVID-19). J Gen Intern Med 2020, 35, 1545-1549, https://doi.org/10.1007/s11606-020-05762-w.

11. McBride, R.; Fielding, B.C. The role of severe acute respiratory syndrome (SARS)-coronavirus accessory proteins in virus pathogenesis. Viruses 2012, 4, 2902-2923, https://doi.org/10.3390/v4112902.

12. Gorbalenya, A.E.; Snijder, E.J.; Spaan, W.J. Severe acute respiratory syndrome coronavirus phylogeny: toward consensus. J Virol 2004, 78, 7863-7866, https://doi.org/10.1128/JVI.78.15.7863-7866.2004.

13. Shang, J.; Zheng, Y.; Yang, Y.; Liu, C.; Geng, Q.; Luo, C.; Zhang, W.; Li, F. Cryo-EM structure of infectious bronchitis coronavirus spike protein reveals structural and functional evolution of coronavirus spike proteins. PLoS pathogens 2018, 14, e1007009, https://doi.org/10.1371/journal.ppat.1007009.

14. Wang, H.I.; Chuang, Z.S.; Kao, Y.T.; Lin, Y.L.; Liang, J.J.; Liao, C.C.; Liao, C.L.; Lai, M.M.C.; Yu, C.Y. Small Structural Proteins E and M Render the SARS-CoV-2 Pseudovirus More Infectious and Reveal the Phenotype of Natural Viral Variants. International journal of molecular sciences 2021, 22, https://doi.org/10.3390/ijms22169087. 
15. Liu, D.X.; Fung, T.S.; Chong, K.K.; Shukla, A.; Hilgenfeld, R. Accessory proteins of SARS-CoV and other coronaviruses. Antiviral Res 2014, 109, 97-109, https://doi.org/10.1016/j.antiviral.2014.06.013.

16. Yeager, C.L.; Ashmun, R.A.; Williams, R.K.; Cardellichio, C.B.; Shapiro, L.H.; Look, A.T.; Holmes, K.V. Human aminopeptidase $\mathrm{N}$ is a receptor for human coronavirus 229E. Nature 1992, 357, 420-422, https://doi.org/10.1038/357420a0.

17. Li, W.; Moore, M.J.; Vasilieva, N.; Sui, J.; Wong, S.K.; Berne, M.A.; Somasundaran, M.; Sullivan, J.L.; Luzuriaga, K.; Greenough, T.C.; et al. Angiotensin-converting enzyme 2 is a functional receptor for the SARS coronavirus. Nature 2003, 426, 450-454, https://doi.org/10.1038/nature02145.

18. van Doremalen, N.; Miazgowicz, K.L.; Milne-Price, S.; Bushmaker, T.; Robertson, S.; Scott, D.; Kinne, J.; McLellan, J.S.; Zhu, J.; Munster, V.J. Host species restriction of Middle East respiratory syndrome coronavirus through its receptor, dipeptidyl peptidase 4. J Virol 2014, 88, 9220-9232, https://doi.org/10.1128/jvi.00676-14.

19. Huang, X.; Dong, W.; Milewska, A.; Golda, A.; Qi, Y.; Zhu, Q.K.; Marasco, W.A.; Baric, R.S.; Sims, A.C.; Pyrc, K.; et al. Human Coronavirus HKU1 Spike Protein Uses O-Acetylated Sialic Acid as an Attachment Receptor Determinant and Employs Hemagglutinin-Esterase Protein as a Receptor-Destroying Enzyme. $J$ Virol 2015, 89, 7202-7213, https://doi.org/10.1128/jvi.00854-15.

20. Ziebuhr, J.; Snijder, E.J.; Gorbalenya, A.E. Virus-encoded proteinases and proteolytic processing in the Nidovirales. J Gen Virol 2000, 81, 853-879, https://doi.org/10.1099/0022-1317-81-4-853.

21. Báez-Santos, Y.M.; St John, S.E.; Mesecar, A.D. The SARS-coronavirus papain-like protease: structure, function and inhibition by designed antiviral compounds. Antiviral Res 2015, 115, 21-38, https://doi.org/10.1016/j.antiviral.2014.12.015.

22. Liu, C.; Zhou, Q.; Li, Y.; Garner, L.V.; Watkins, S.P.; Carter, L.J.; Smoot, J.; Gregg, A.C.; Daniels, A.D.; Jervey, S.; et al. Research and Development on Therapeutic Agents and Vaccines for COVID-19 and Related Human Coronavirus Diseases. ACS central science 2020, 6, 315-331, https://doi.org/10.1021/acscentsci.0c00272.

23. Wu, Z.; McGoogan, J.M. Characteristics of and Important Lessons From the Coronavirus Disease 2019 (COVID-19) Outbreak in China: Summary of a Report of 72314 Cases From the Chinese Center for Disease Control and Prevention. Jama 2020, 323, 1239-1242, https://doi.org/10.1001/jama.2020.2648.

24. Welliver, R.; Monto, A.S.; Carewicz, O.; Schatteman, E.; Hassman, M.; Hedrick, J.; Jackson, H.C.; Huson, L.; Ward, P.; Oxford, J.S.; et al. Effectiveness of oseltamivir in preventing influenza in household contacts: a randomized controlled trial. JAMA 2001, 285, 748-754, https://doi.org/10.1001/jama.285.6.748.

25. Yao, X.; Ye, F.; Zhang, M.; Cui, C.; Huang, B.; Niu, P.; Liu, X.; Zhao, L.; Dong, E.; Song, C.; et al. In Vitro Antiviral Activity and Projection of Optimized Dosing Design of Hydroxychloroquine for the Treatment of Severe Acute Respiratory Syndrome Coronavirus 2 (SARS-CoV-2). Clin Infect Dis 2020, 71, 732-739, https://doi.org/10.1093/cid/ciaa237.

26. Fox, R.I. Mechanism of action of hydroxychloroquine as an antirheumatic drug. Seminars in arthritis and rheumatism 1993, 23, 82-91, https://doi.org/10.1016/s0049-0172(10)80012-5.

27. Elfiky, A.A. Anti-HCV, nucleotide inhibitors, repurposing against COVID-19. Life Sci 2020, 248, 117477, https://doi.org/10.1016/j.lfs.2020.117477.

28. Maxmen, A. More than 80 clinical trials launch to test coronavirus treatments. Nature 2020, 578, 347-348, https://doi.org/10.1038/d41586-020-00444-3.

29. Khalili, J.S.; Zhu, H.; Mak, N.S.A.; Yan, Y.; Zhu, Y. Novel coronavirus treatment with ribavirin: Groundwork for an evaluation concerning COVID-19. Journal of medical virology 2020, 92, 740-746, https://doi.org/10.1002/jmv.25798.

30. Md Insiat Islam, R. Current Drugs with Potential for Treatment of COVID-19: A Literature Review. Journal of pharmacy \& pharmaceutical sciences : a publication of the Canadian Society for Pharmaceutical Sciences, Societe canadienne des sciences pharmaceutiques 2020, 23, 58-64, https://doi.org/10.18433/jpps31002.

31. Cai, Q.; Yang, M.; Liu, D.; Chen, J.; Shu, D.; Xia, J.; Liao, X.; Gu, Y.; Cai, Q.; Yang, Y.; et al. Experimental Treatment with Favipiravir for COVID-19: An Open-Label Control Study. Engineering (Beijing, China) 2020, 6, 1192-1198, https://doi.org/10.1016/j.eng.2020.03.007.

32. Liu, F.; Xu, A.; Zhang, Y.; Xuan, W.; Yan, T.; Pan, K.; Yu, W.; Zhang, J. Patients of COVID-19 may benefit from sustained Lopinavir-combined regimen and the increase of Eosinophil may predict the outcome of COVID-19 progression. International journal of infectious diseases : IJID : official publication of the International Society for Infectious Diseases 2020, 95, 183-191, https://doi.org/10.1016/j.ijid.2020.03.013.

33. Elfiky, A.A. Ribavirin, Remdesivir, Sofosbuvir, Galidesivir, and Tenofovir against SARS-CoV-2 RNA dependent RNA polymerase (RdRp): A molecular docking study. Life Sci 2020, 253, 117592, https://doi.org/10.1016/j.lfs.2020.117592.

34. Lythgoe, M.P.; Middleton, P. Ongoing Clinical Trials for the Management of the COVID-19 Pandemic. Trends in pharmacological sciences 2020, 41, 363-382, https://doi.org/10.1016/j.tips.2020.03.006.

35. Pant, S.; Singh, M.; Ravichandiran, V.; Murty, U.S.N.; Srivastava, H.K. Peptide-like and small-molecule inhibitors against Covid-19. J Biomol Struct Dyn 2021, 39, 2904-2913, https://doi.org/10.1080/07391102.2020.1757510. 
36. Grein, J.; Ohmagari, N.; Shin, D.; Diaz, G.; Asperges, E.; Castagna, A.; Feldt, T.; Green, G.; Green, M.L.; Lescure, F.X.; et al. Compassionate Use of Remdesivir for Patients with Severe Covid-19. The New England journal of medicine 2020, 382, 2327-2336, https://doi.org/10.1056/NEJMoa2007016.

37. Liu, C.; Zhou, Q.; Li, Y.; Garner, L.V.; Watkins, S.P.; Carter, L.J.; Smoot, J.; Gregg, A.C.; Daniels, A.D.; Jervey, S. Research and development on therapeutic agents and vaccines for COVID-19 and related human coronavirus diseases2020, https://www.prosci-inc.com/covid-19/.

38. Le, T.T.; Andreadakis, Z.; Kumar, A.; Roman, R.G.; Tollefsen, S.; Saville, M.; Mayhew, S. The COVID-19 vaccine development landscape. Nat Rev Drug Discov 2020, 19, 305-306.

39. Li, S.Y.; Chen, C.; Zhang, H.Q.; Guo, H.Y.; Wang, H.; Wang, L.; Zhang, X.; Hua, S.N.; Yu, J.; Xiao, P.G.; et al. Identification of natural compounds with antiviral activities against SARS-associated coronavirus. Antiviral Res 2005, 67, 18-23, https://doi.org/10.1016/j.antiviral.2005.02.007.

40. Kumar, V.; Jung, Y.S.; Liang, P.H. Anti-SARS coronavirus agents: a patent review (2008 - present). Expert Opin Ther Pat 2013, 23, 1337-1348, https://doi.org/10.1517/13543776.2013.823159.

41. Lin, L.T.; Hsu, W.C.; Lin, C.C. Antiviral natural products and herbal medicines. J Tradit Complement Med 2014, 4, 24-35, https://doi.org/10.4103/2225-4110.124335.

42. Lin, C.W.; Tsai, F.J.; Tsai, C.H.; Lai, C.C.; Wan, L.; Ho, T.Y.; Hsieh, C.C.; Chao, P.D. Anti-SARS coronavirus 3C-like protease effects of Isatis indigotica root and plant-derived phenolic compounds. Antiviral Res 2005, 68, 36-42, https://doi.org/10.1016/j.antiviral.2005.07.002.

43. Ryu, Y.B.; Jeong, H.J.; Kim, J.H.; Kim, Y.M.; Park, J.Y.; Kim, D.; Nguyen, T.T.; Park, S.J.; Chang, J.S.; Park, K.H.; et al. Biflavonoids from Torreya nucifera displaying SARS-CoV 3CL(pro) inhibition. Bioorganic \& medicinal chemistry 2010, 18, 7940-7947, https://doi.org/10.1016/j.bmc.2010.09.035.

44. Yu, M.S.; Lee, J.; Lee, J.M.; Kim, Y.; Chin, Y.W.; Jee, J.G.; Keum, Y.S.; Jeong, Y.J. Identification of myricetin and scutellarein as novel chemical inhibitors of the SARS coronavirus helicase, nsP13. Bioorganic \& medicinal chemistry letters 2012, 22, 4049-4054, https://doi.org/10.1016/j.bmcl.2012.04.081.

45. Shah, A.; Patel, V.; Parmar, B. Discovery of Some Antiviral Natural products to fight against Novel Corona Virus (SARS-CoV-2) using Insilico approach. Combinatorial chemistry \& high throughput screening 2020, https://doi.org/10.2174/1386207323666200902135928.

46. Lau, K.M.; Lee, K.M.; Koon, C.M.; Cheung, C.S.; Lau, C.P.; Ho, H.M.; Lee, M.Y.; Au, S.W.; Cheng, C.H.; Lau, C.B.; et al. Immunomodulatory and anti-SARS activities of Houttuynia cordata. $J$ Ethnopharmacol 2008, 118, 79-85, https://doi.org/10.1016/j.jep.2008.03.018.

47. Cheng, P.W.; Ng, L.T.; Chiang, L.C.; Lin, C.C. Antiviral effects of saikosaponins on human coronavirus 229E in vitro. Clin Exp Pharmacol Physiol 2006, 33, 612-616,https://doi.org/10.1111/j.14401681.2006.04415.x.

48. Sewani-Rusike, C.R.; Mammen, M. Medicinal plants used as home remedies: a family survey by first year medical students. African journal of traditional, complementary, and alternative medicines : AJTCAM 2014, 11, 67-72, https://doi.org/10.4314/ajtcam.v11i5.11.

49. Chang, S.J.; Chang, Y.C.; Lu, K.Z.; Tsou, Y.Y.; Lin, C.W. Antiviral Activity of Isatis indigotica Extract and Its Derived Indirubin against Japanese Encephalitis Virus. Evidence-based complementary and alternative medicine : eCAM 2012, 2012, 925830, https://doi.org/10.1155/2012/925830.

50. Li, J.; Zhao, F. Anti-inflammatory functions of Houttuynia cordata Thunb. and its compounds: A perspective on its potential role in rheumatoid arthritis. Exp Ther Med 2015, 10, 3-6, https://doi.org/10.3892/etm.2015.2467.

51. Dhama, K.; Sachan, S.; Khandia, R.; Munjal, A.; Iqbal, H.M.N.; Latheef, S.K.; Karthik, K.; Samad, H.A.; Tiwari, R.; Dadar, M. Medicinal and Beneficial Health Applications of Tinospora cordifolia (Guduchi): A Miraculous Herb Countering Various Diseases/Disorders and its Immunomodulatory Effects. Recent patents on endocrine, metabolic \& immune drug discovery 2017, 10, 96-111, https://doi.org/10.2174/1872214811666170301105101.

52. Młynarczyk, K.; Walkowiak-Tomczak, D.; Łysiak, G.P. Bioactive properties of Sambucus nigra L. as a functional ingredient for food and pharmaceutical industry. Journal of functional foods 2018, 40, 377-390, https://doi.org/10.1016/j.jff.2017.11.025.

53. Alzohairy, M.A. Therapeutics Role of Azadirachta indica (Neem) and Their Active Constituents in Diseases Prevention and Treatment. Evidence-based complementary and alternative medicine : eCAM 2016, 2016, 7382506, https://doi.org/10.1155/2016/7382506.

54. Krishnaveni, M.; Mirunalini, S. Therapeutic potential of Phyllanthus emblica (amla): the ayurvedic wonder. Journal of basic and clinical physiology and pharmacology 2010, 21, 93-105, https://doi.org/10.1515/jbcpp.2010.21.1.93.

55. Wilson, E.; Rajamanickam, G.V.; Dubey, G.P.; Klose, P.; Musial, F.; Saha, F.J.; Rampp, T.; Michalsen, A.; Dobos, G.J. Review on shilajit used in traditional Indian medicine. J Ethnopharmacol 2011, 136, 1-9, https://doi.org/10.1016/j.jep.2011.04.033.

56. Madaan, A.; Kanjilal, S.; Gupta, A.; Sastry, J.L.; Verma, R.; Singh, A.T.; Jaggi, M. Evaluation of immunostimulatory activity of Chyawanprash using in vitro assays. Indian journal of experimental biology 2015, 53, 158-163. 
57. Mak, K.K.; Pichika, M.R. Artificial intelligence in drug development: present status and future prospects. Drug Discov Today 2019, 24, 773-780, https://doi.org/10.1016/j.drudis.2018.11.014.

58. Baig, M.H.; Ahmad, K.; Roy, S.; Ashraf, J.M.; Adil, M.; Siddiqui, M.H.; Khan, S.; Kamal, M.A.; Provazník, I.; Choi, I. Computer Aided Drug Design: Success and Limitations. Curr Pharm Des 2016, 22, 572-581, https://doi.org/10.2174/1381612822666151125000550.

59. Robson, B. Computers and viral diseases. Preliminary bioinformatics studies on the design of a synthetic vaccine and a preventative peptidomimetic antagonist against the SARS-CoV-2 (2019-nCoV, COVID-19) coronavirus. Comput Biol Med 2020, 119, 103670, https://doi.org/10.1016/j.compbiomed.2020.103670.

60. Kovach, C.R.; Taneli, Y.; Neiman, T.; Dyer, E.M.; Arzaga, A.J.; Kelber, S.T. Evaluation of an ultraviolet room disinfection protocol to decrease nursing home microbial burden, infection and hospitalization rates. BMC Infect Dis 2017, 17, 186, https://doi.org/10.1186/s12879-017-2275-2.

61. Leipheimer, J.M.; Balter, M.L.; Chen, A.I.; Pantin, E.J.; Davidovich, A.E.; Labazzo, K.S.; Yarmush, M.L. First-in-human evaluation of a hand-held automated venipuncture device for rapid venous blood draws. Technology (Singap World Sci) 2019, 7, 98-107, https://doi.org/10.1142/s2339547819500067.

62. Yang, G.Z.; B, J.N.; Murphy, R.R.; Choset, H.; Christensen, H.; S, H.C.; Dario, P.; Goldberg, K.; Ikuta, K.; Jacobstein, N.; et al. Combating COVID-19-The role of robotics in managing public health and infectious diseases. Science robotics 2020, 5, https://doi.org/10.1126/scirobotics.abb5589.

63. van Griensven, J.; Edwards, T.; de Lamballerie, X.; Semple, M.G.; Gallian, P.; Baize, S.; Horby, P.W.; Raoul, H.; Magassouba, N.; Antierens, A.; et al. Evaluation of Convalescent Plasma for Ebola Virus Disease in Guinea. The New England journal of medicine 2016, 374, 33-42, https://doi.org/10.1056/NEJMoa1511812.

64. Zhou, B.; Zhong, N.; Guan, Y. Treatment with convalescent plasma for influenza A (H5N1) infection. The New England journal of medicine 2007, 357, 1450-1451, https://doi.org/10.1056/NEJMc070359.

65. Cheng, Y.; Wong, R.; Soo, Y.O.; Wong, W.S.; Lee, C.K.; Ng, M.H.; Chan, P.; Wong, K.C.; Leung, C.B.; Cheng, G. Use of convalescent plasma therapy in SARS patients in Hong Kong. European journal of clinical microbiology \& infectious diseases: official publication of the European Society of Clinical Microbiology 2005, 24, 44-46, https://doi.org/10.1007/s10096-004-1271-9. 